\title{
Coupling phytoremediation and biofuel production by using sea buckthorn
}

\author{
Lesya Shevchyk, Olga Romaniuk
}

\begin{abstract}
Department of Physical Chemistry of Fossil Fuels of the Institute of Physical-Organic Chemistry and Coal Chemistry named after L. M. Lytvynenko of the National Academy of Sciences of Ukraine, UKRAINE, Lviv, Naukova street 3a, E-mail: lesyashevchik@gmail.com
\end{abstract}

\begin{abstract}
In this paper coupling phytoremediation and biofuel production by using Sea buckthornis given. Sea buckthorn brings many environmental benefits, including soil and water conservation, desertification control, land reclamation, erosion and water loss control, and the establishment of wild life habitats especially in fragile ecosystem due to its extensive root system coupled with efficient nitrogen fixation. Sea buckthorn has proved to be a popular green energy plant because of its quality biomass. It is a good source of firewood. The usage of Sea buckthorn oil is an effective biodiesel over other bio diesels formed from other vegetable oils.
\end{abstract}

Keywords - biofuel, phytoremediation, firewood, biodiesel, Sea buckthorn, Hippophae rhamnoides L.

\section{Introduction}

The world is confronted with the twin crisis of fossil fuel depletion and environmental degradation. Phytoremediation has been increasingly used as a more sustainable approach for the remediation of contaminated sites. The costs associated with this remediation method are usually lower than other well-known remediation technologies and some environmental impacts, like atmospheric emissions and waste generation, are inexistent. The biomass produced in phytoremediation could be economically valorized in the form of bioenergy (biogas, biofuels and combustion for energy production and heating), representing an important environmental cobenefit, added to others such as erosion control, improving soil quality and functionality, and providing wildlife habitat. Biomass-based energy is increasingly gaining popularity as a relatively clean, renewable and carbon-neutral alternative to fossil fuels. Coupling phytoremediation and biofuel production by using fast-growing species having bioenergy potential appears to be a rather attractive opportunity.

\section{Results and discussion}

We have found that Sea buckthorn is suitable for phytoremediation of oil-contaminated soils. Hippophae rhamnoides L. plants successfully adapt to adverse conditions of the oilcontaminated soils, improves physical, chemical and biological properties of soils, decrease their toxicity, reduce the amount of the contained oil, provide long-term phytoremediation and easily spread to unoccupied areas. The degree of soil cleaning from oil pollution reaches $92,7 \%$ [1].

Sea buckthorn is an ecologically and economically important plant that belongs to the family Elaegnaceae. The plant is hardy and it can withstand extreme temperatures from $-40{ }^{\circ} \mathrm{C}$ to $40{ }^{\circ} \mathrm{C}$. Sea buckthorn leaves are small, cuticle is thicker, crib-texture is well developed, leaf back densely covered with scales and star-hair to cover stoma. Seabuckthorn has a strong and welldeveloped tap root system, having primary, secondary and tertiary roots covered with root hairs. About $80 \%$ of its primary (feeding) roots are in the surface soil $(0,2$ to $0,8 \mathrm{~m})$ which helps in preventing erosion. Sea buckthorn plantation intercepts precipitation by lush crown layer which redistribute precipitation and control surface runoff. Root nodules of $H$. rhamnoides have a symbiotic association with bacterium belonging to the genus Frankia having the ability to fix nitrogen from the air. It has been found that Sea buckthorn can fix upto $180 \mathrm{~kg}$ of nitrogen per ha per year, which generally improves soil fertility. They also transform insoluble organic and mineral matters from the soil to more soluble states. Plantation of Sea buckthorn improves soil physical characteristics and fertility thereby improves soil water holding capacity. It has been 
observed that soil moisture in Sea buckthorn plantation areas is 3-4\% higher than outside the forest. Similarly air humidity is 10-20\% higher in Sea buckthorn forest. The shrub has been found growing well in sandy, rocky, saline and ravine soils. Since it is resistant to drought and tolerates soil salinity and low temperatures, it is suitable for many situations that are simply too demanding for most plants. Thorny and bushy growth of Sea buckthorn provides a protective shelter for flora and fauna thereby maintaining the fragile ecosystem $[1,2]$.

Sea buckthorn has proved to be a popular green energy plant because of its quality biomass. It is a good source of firewood. In a six-year old Sea buckthorn forest, each hectare can produce 18 tons of firewood, equal to nearly 12,6 tons of standard coal [2]. The heat value of Sea buckthorn wood is $4785,5 \mathrm{kcal} / \mathrm{kg}$, and so it can be used as a substitute for coal in various applications for burning.

Sea buckthorn oil is an good option for the manufacture of biodiesel. Biodiesel is an alternative energy source and could be a substitute for petroleum-based diesel fuel. Biodiesel burns clean, which results in a significant reduction of the types of pollutants that contribute to smog and global warming and emits up to $85 \%$ fewer cancercausing agents. Biodiesel refers to a vegetable oil or animal fat based diesel fuel consisting of long-chain alkyl (methyl, propyl or ethyl) esters. Biodiesel is meant to be used in standard diesel engines and is thus distinct from the vegetable and waste oils used to fuel converted diesel engines. Biodiesel can be used alone, or blended with petrol or diesel. It is found that the seabuckthorn oil is an effective biodiesel over other bio diesels formed from other vegetable oils. It has low viscosity among vegetable oils. Oils from Sea-buckthorn seeds and pulp differ considerably in fatty acid composition. While linoleic acid and $\alpha$-linolenic acid are the major fatty acids in seed oil, sea buckthorn pulp oil contains approximately $65 \%$ combination of the monounsaturated fatty acid, palmitoleic acid, saturated fatty acid and palmitic acid [3].

\section{Conclusion}

In this paper coupling phytoremediation and biofuel production by using Sea buckthorn is given. The plant brings many environmental benefits, including soil and water conservation, desertification control, land reclamation, erosion and water loss control, and the establishment of wild life habitats especially in fragile ecosystem due to its extensive root system coupled with efficient nitrogen fixation. Sea buckthorn has proved to be a popular green energy plant because of its quality biomass. It is a good source of firewood. The heat value of seabuckthorn wood is $4785,5 \mathrm{kcal} / \mathrm{kg}$. The usage of Sea buckthorn oil is an effective biodiesel over other bio diesels formed from other vegetable oils.

\section{References}

[1] L. Z. Shevchyk, O. I. Romaniuk, "Phytoremediation of oil contaminated soil using Sea Buckthorn," Biological Bulletin of Bogdan Chmelnitskiy Melitopol State Pedagogical University, vol. 6 (3), pp. 472-480, 2016.

[2] Mohit Husain, Jagdeesh Prasad Rathore, Aatifa Rasool, Aafaq A Parrey, Dinesh Kumar Vishwakarma and Kolagani Mahendar, "Seabuckthorn: A multipurpose shrubs species in Ladakh cold desert," Journal of Entomology and Zoology Studies, vol. 6, no. 2 pp. 13301337, 2018.

[3] S. S Varun Shankar, Vinoth. B, R. Dinesh, S. Anand, Elangovan and S. Srikanth, "Biodiesel from Seabuckthorn Oil," International Journal of Chemical Engineering and Applications vol. 1, no. 1, pp. 15-19, 2010. 